"Influence of the minimum salary level increase on the business entities activity in the context of the transition to the sustainable development"

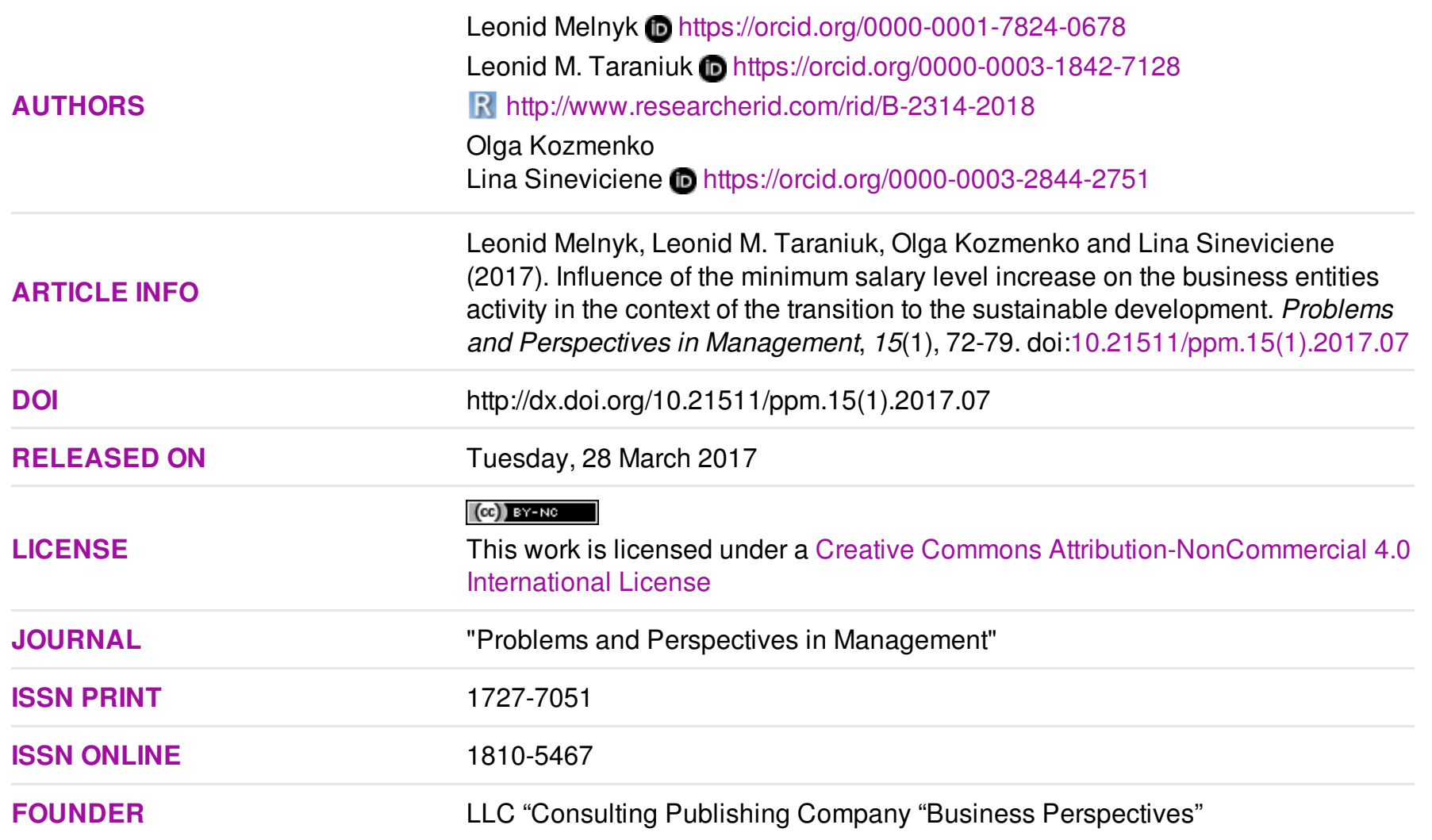

NUMBER OF REFERENCES

20
NUMBER OF FIGURES

2
NUMBER OF TABLES

2

(C) The author(s) 2023. This publication is an open access article. 

(Lithuania)

\title{
Influence of the minimum salary level increase on the business entities activity in the context of transition to the sustainable development
}

\begin{abstract}
In the context of transition to the sustainable development actually justified and economically balanced managerial decisions are worth to be introduced into activity of the business entities. First of all, it is connected with the formation of the social standards by the Ukrainian government. Establishment of the minimum salary for the employees of the national economic complex of the country is one of the main components of these standards. This indicator influences both the increase of the population's social welfare provision level and on the economy of the economic entities, including business representatives. Research was conducted in Ukraine. The main trends of the social welfare provision of the business sector entities, including the experience of Hungary and Russia, were analyzed in this article. The main rules of the effective social welfare provision, accounting the necessities of the business environment, were formed. Economical analysis of the retrospective and predictive information about the payroll payment and payment of social contributions was made. The influence of the increase of the minimum salary on the activity of business entities, taking into account raised minimum salary, was analyzed. The regressive model of the payroll budget dependence, accounting minimum salary and social contributions' level increase, was designed. Obtained calculation results showed high level of tax burden on the business sector entities, so, organization-economic measures of tax burden decrease on the business entities were offered. They took into account minimum salary growth for their employees in the context of the transition to the sustainable development. Recommendations concerning the further scientific researches on the topic of the article were offered.
\end{abstract}

Keywords: salary, business entities, social contributions, tax burden, pattern.

JEL Classification: M21, M29.

\section{Introduction}

In the context of constant transformations of the work of real, private, state and external sectors of economy, which determine the transition to the sustainable development, in the activity of business entities, special attention should be paid to the formation of the effective policy of employees' social welfare provision. We use the term sustainable development to mean the formation of the new patterns of introduction of economy ecologization concept and balanced variant of its development assurance (Strochenko, N.I., 2014). There exist a lot of factors, which influence in the negative way on the realization of this policy by business organizations. Examining this issue and accounting that the study was conducted in Ukraine, the main statistical markers of the social development of the country's economy sectors, including business sector, in 20152016, should be analyzed.

(C) Leonid Melnyk, Leonid Taraniuk, Olga Kozmenko, Lina Sineviciene, 2017

Leonid Melnyk, D.Sc. (Economy), Professor, Head of Economics and Business Administration Department of Sumy State University, Ukraine.

Leonid Taraniuk, D.Sc. (Economy), Professor, Associate Professor of Economics and Business Administration Department of Sumy State University, Ukraine.

Olga Kozmenko, Dr., Professor of Department of Finance, Kharkiv National University of Economics, Ukraine.

Lina Sineviciene, Dr. in Economics, Lecturer of Department of Finance, School of Economics and Business, Kaunas University of Technology, Lithuania.

This is an Open Access article, distributed under the terms of the Creative Commons Attribution-NonCommercial 4.0 International license, which permits re-use, distribution, and reproduction, provided the materials aren't used for commercial purposes and the original work is properly cited.
Thus, the average gross wages in August 2016 were equal to 5202 UAH (203 USD according to the exchange rate of National Bank of Ukraine for the moment of estimation), which is 3.6 times higher than the minimum wages (1450 UAH (57 USD)). In relation to the August 2015, the amount of the minimum wages increased for $23.7 \%$ (Anti-crisis Program of Joint Actions of Government and Business: Urgent Solutions, 2016). During the period from January till September 2016, the amount of backdated wages comprised 1902.3 mln UAH (74164 USD). Rate of increase of the backdated wages to the employees is $94.2 \%$ (September 2016 relatively to the September 2015). The quantity of the officially unemployed workers in 2015 was 490.8 thousand persons (multi-industry statistic information, 2016). Examining the level of the backdated wages, it is necessary to state that it is a negative issue, which influences the reduction of motivation to the effective work of the staff of business organizations and, in its turn, it influences economical indexes of business entities' economical activity.

On the modern level of productive forces' development, the Government of Ukraine in its socialeconomic programs introduces the policy of the social standards' increase. It takes into account the rate of minimum wages for the employees of different business patterns, and it does not take into account increase of tax burden on the business entities.

It is necessary to state that in terms of modern market relations in the country's economy to the negative consequences of wages increase one should refer: to low level of real income of the population, low level of pension provision, inflation risks, high level of tax 
burden, strengthening of fiscal control, raise of corruption (News of Ukrainian League of Industrialists and Entrepreneurs, 2016).

All mentioned above conditions the timeliness of the research topic and its main aim, which is in the implementation of the complex economical justification of influence of labor remuneration level increase on the economic activity of the business entities in the context of transition to the sustainable development. The subject of the research in this article is the development of theoretical and methodological issues as to the formation of the social standards in the business organizations' activity. Under the term "business entities", we mean entities of economic relations, which perform business activities (Makhinchuck, 2013).

\section{Brief literature review}

1.1. Social-economic system in the context of transition to the sustainable development. During the investigation of the social-economic system it is necessary to state importance of its formation and functioning in the context of transition to the sustainable development. In the work of L.G. Melnik, the preconditions of self-organization of open steady-state systems are examined, the main rules of system's functioning and development are formed, the factors, which distinguish the speed of development of socialeconomic systems, are analyzed (Melnik, 2010). Formation of innovation strategies in the development of social-economic systems for the increase of "green" economy efficiency level was investigated in the group work of L.G. Melnyk, O.V. Shkarupaand M.O. Kharchenko (Melnyk, ShkarupaandKharchenko, 2013). Moreover, creation of the favorable social-economic and regulatory climate for their further sustainable development is an important issue in the effective functioning of socialeconomic system. In the article of I. Sotnyk, T. Kurbatova, and G. Khlyap (Sotnyk, Kurbatova and Khlyap, 2014) economical, social and legislative problematic issues of improvement of activity of the objects of state renewable energy sector in the context of transition to the sustainable development were studied. It is also necessary to mention the role of business organizations as the entities of socialeconomic system in its functioning, which means to distinguish organization-economic and social interaction between the business companies and state authorities. Improvement of administration system of small and medium-sized business in the context of crisis by means of formation of the interaction pattern between the enterprises and regional authorities in order to guarantee the business entities' viability and to increase the efficiency of the regional economic policy, including the raise of social standards and norms, were studied in their work by A.V. Kundenko, M.S. Dorosh, I. A. Baraniuk and D.M. Ilchenko (Kundenko, Dorosh, Baraniuk, and Itchenko, 2015).
1.2. Social determinants in business entities' activity. One of the main features of the system's sustainable development is the increase of the level of employees' social protection, which is also characterized by the growth of the payroll budget at the enterprises of various forms of incorporation. In this research it is necessary to take into account the interference of "grey" economy into social welfare provision in the business organizations activity. The influence of the level of "grey" economy on the financial provision of the social protection was studied with the help of economic-statistic methods in the works of scientistseconomists M.I. Malyovanyi, O.V. Rolinskyi and N.V. Lysa (Malyovanyi, Rolinskyi and Lysa, 2016). Obtained results state the fact that countries with higher level of "grey" economy have lower social expenditures per one person. First of all, it is connected with the reduction of funding sources for social protection (Malyovanyi, Rolinskyi and Lysa, 2016). Studying of human capital assets in the social business activity is an important issue which was studied by the scientistseconomists S. Estrin, S. Mickiewicz, and U. Stephan (Estrin, Mickiewicz, and Stephan, 2016). In our opinion it allows to focus attention on the formation of the intelligent potential in the employees of the business sector companies and also on the effective system of labour remuneration in the company. The individual motivation component should be taken into account while the investigation of the role of social entrepreneurship in the creation of effective system of employees' labor remuneration. The article of the scientists O.Irengun and S.Arikboga was devoted to these issues (Irengun and Arikboga, 2015).

1.3. Labour remuneration in the activities of business entities. The level of employees' labour remuneration plays an important role in the effective social welfare provision of the enterprise. J. Chesloch and T. Callie were researching the changes of the labour remuneration in the consulting companies and educational establishments (Cheslock and Callie, 2015). They established the differences between the businesssectors and levels of state funding of these sectors. While studying of labour remuneration key features it is necessary to pay attention to the salary structure in various categories of employees. Thus, in the works of scientists M. Maluland A. Shoham (Malul and Shoham, 2013) special features of salary accounting for the top-management depending on its real qualification are studied. Authors of this article consider it to be the basic feature for the establishment of the level of labour remuneration according to qualification of the company's top-management and its possibilities to adopt effective managerial decisions. .

A valuable issue in the research of remuneration changes in business structures is the study of resource possibilities of business organizations, which can be directed to increase of employees' labour remuneration. This problem was studied in the work of scien- 
tists V. Ng and D. Feldman (Ng and Feldman, 2014), in which scientists studied the problematic issues of financial resources preservation and delays in the reaching high level of labour remuneration because of career. The issues of negotiations between the employer and employee concerning the changes in the remuneration, namely development of flexible approach to the interconnection between the chief and the subordinate in the sphere of the establishment of the optimum level of remuneration for both sides, were studied in the work of the scientist D. More (More, 2014).

Among the research works, devoted to the role of labor remuneration and social welfare provision in the activity of business organizations, little attention is devoted to the establishment of dependence between the payroll budget growth and social contributions, which are compulsory to be paid by the entrepreneurs. That is why this issue is to be studied in this article. Scientific hypothesis implies the improvement of methodology of influence of labour remuneration growth on the activity of the business sector entities in the context of transition to the sustainable development.

\section{Methodology}

2.1 Research approach. During the scientific research for the furtherance of its main goal the method of comparative analysis of the main economical indicators was used. These indicators characterize the processes of labor remuneration in the entrepreneurs' activities. There was also used the methodological approach, which included economical modeling of the processes of influence of labor remuneration growth on the tax burden, which in its turn, influenced on the economical activity of business organizations in general. This economical modeling characterizes the formation of regressive functional relation between the payroll budget, accounting minimum wages growth, and social contributions.

2.2 Participants. Information for economical substantiation of influence of the level of labor remuneration growth on the tax burden in the activity of business organizations was taken from the companies' financial data reporting, namely, from the report about financial results of the business sector companies, which perform project activities. Names of the companies are the following: TOV "BBB" (Sumy), TOV "Avtogazproject" (Dnipro), TOV "LMG" (Sumy) (all companies of Limited Liability Partnership). All staff categories of these companies were examined, that was in total, administrative officers $-20 \%$, engineers $70 \%$, junior labour $-10 \%$. Information about the labour remuneration of these employees is taken into account while calculating tax burden in the activity of economic entities.

2.3 Measuring toolkit. During the economical substantiation of the influence of the labour remuneration growth on the tax rate in the activity of business organ- izations, authors of this article used the comparative method of economic indexes, special features of which were researched by the scientists T.A. Gorodnia and N.S. Kanyuka (Gorodnia and Kanyuka, 2012). Principle of the method is in the usage of economical markers, which characterize the level of labor remuneration, namely the level of salary itself, salary supplements and rewards that in total comprise the main and additional labour remuneration of the employees and also the level of social contributions, which is characterized by the united social tax, personal income tax rate and war tax. While conducting of this comparative analysis, economical model will be formed. It characterizes the regressive functional relation between four variables (payroll budget, united social tax, personal income tax, and war tax) and formation of the mathematical level of dependence of the payroll budget and social contributions. Special features of forecasting with the help of regressive functional relation were accepted as the background of the estimation by scientists A.V. Kalinichenko and Y.V. Shmigol (Kalinichenko and Shmigol, 2012). Special features of regressive functional relation between the employees' remuneration and their skills, which was offered by G. Gilpin will also be included into these toolkit (Gilpin, 2012).

2.4. Procedure. During research, the data of the business entities'statistical reporting were collected. These data concern remuneration to the employees of the business organizations during 2015-2016. Here, staff categories, receiving the minimum salary within the correspondent period of analyzed time period, were taken into account. Obtained results were used for research purposes only.

2.5. Statistical analysis. Comparative analysis of the statistical reporting of business organizations about labour remuneration was conducted. During the investigation regression analysis for formation of regressive functional relation between the payroll budget, which is influenced by the minimum level of labour remuneration, and the amount of social contributions of the business entities under examination, were used.

\section{Results}

3.1 analytical and theoretical issues. During the study of organization-economic issues, the level of social standards in the country should be distinguished. Dynamic patterns of the growth of the minimum salary in Ukraine during 2004-2015 should be analyzed. It was established that in the period $2004-2015$, in Ukraine there took place the dynamic pattern of the initial increase of the minimum labor remuneration in the equivalent Dollar amount, and in the period 2012-2015, inclusive the dynamic pattern was negative, as the decrease of the level of minimum labor remuneration from 134.29 USD till 57.42 USD (difference 76.87 USD) took place. 


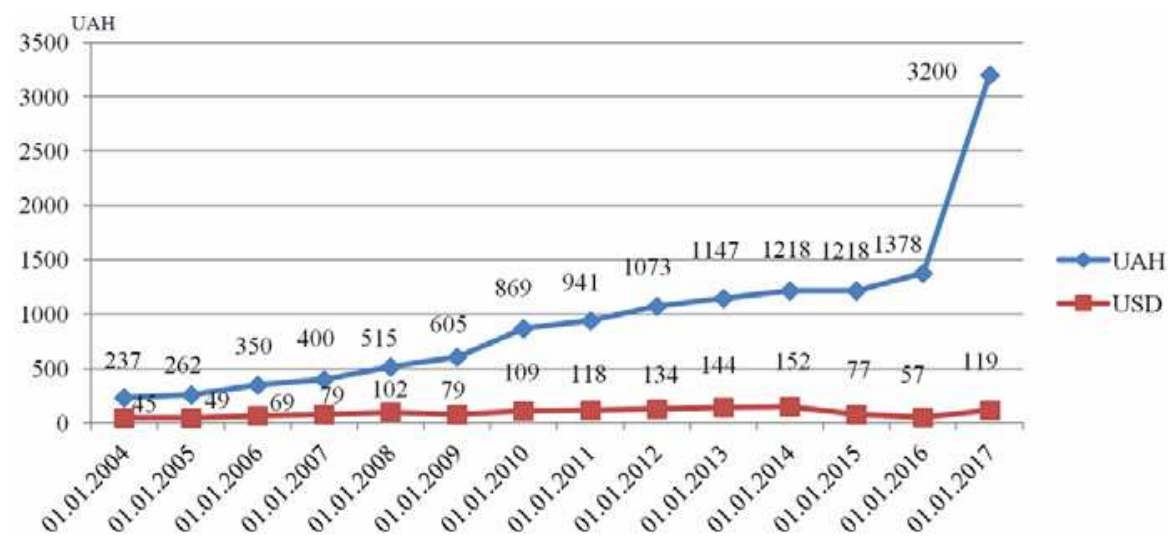

Fig. 1. Dynamic pattern of the minimum labor remuneration growth in Ukraine during the period 2004-2015 (Polischuk, 2015)

According to the data of Ministry of Social Policy of Ukraine, minimum salary is officially received in Ukraine by $3.7 \mathrm{mln}$ employees $(2.6 \mathrm{mln}$ employees in the private sector). Taking into account that in 2015, quantity of the working population was equal to 16.4 $\mathrm{mln}$ people, the minimum salary was received by more than $20 \%$ of employees. For comparison, in 2014 among $77.2 \mathrm{mln}$ USA employees, who were paid wages, about $3 \mathrm{mln}$ were remunerated with the federally adopted minimum wages, which amounted $7.25 \$$ per hour or even lower wages (in total 3.8\%). In Poland about $10.5 \%$ of employees were remunerated in the amount lower than minimum wages (Gorodnichenko and Talaver, 2016).

It was established that the situation, which leads to the shadowing of relations between the employer and employee, is observed. It is better for the business entities to show minimum salary in the income declaration than to set high salary to the employees and pay high taxes. As a result, these processes lead to the decrease of income into the country's budget. The steps of the country government's policy aimed at the social standards'raising in order to increase budget's income are quite understandable.

In scientific practice M. Tonin (Tonin, 2011), Hungarian scientist, studies Hungarian practice of the minimum salary growth. In 2000 in Hungary the minimum salary was on the level of 25000 HUF, in $2001-40000$ HUF. It was found out that while the increase of the social welfare provision, the part of the employees, who lose their working places because of the growth of the employer expenditures for the labour resources, also increases.

Also, the practice, of the minimum salary increase, which was introduced by the Russian government in 2007, should be noted.From the scientific point of view this phenomenon was studied by $\mathrm{O}$. Muravyev and O. Oschepkov (Muravyev and Oshchepkov, 2015), both scientists-economists. It was discovered that minimum salary growth led to: shadow payments growth, young people employment decrease, creation of new shadow working places, decrease of guarantee level of social welfare provision.
During the formation of the effective social policy, aimed at increase of the social standards level, it is necessary to work out main rules of effective social welfare provision which take into account necessities of the business entities. They characterize the effective direction of the minimum labor remuneration increase for all entities of this process.

The authors refer to the following rules:

- equilibrium principle, which characterizes balanced increase of social standards, accounting economic situation in the country, price level, paying capacity of the population;

- pro rata principle, which establishes the dependence between the labor remuneration increase and level of the tax burden, which has to be optimum for performing effective business activity.

- principle of equality, which includes equal rights among all participants of the process before the law and their keeping to laws and regulations. The participants are: entrepreneurs, employees, taxation bodies;

- principle of non-refoulement, which contains the realization of the components of the sustainable development in the entrepreneurs' activity. It means that business-processes of the business organizations have to be aimed at stable growth, social responsibility and increase of the business competitiveness level.

It is necessary to state that the problems of violation of the legislative regulation by the enterprise administration during the minimum salary accounting, which is characterized by the principle of equality, were studied in his works by the scientist O.M. Pyshulina (Pyshulina, 2007). Functions of the labor remuneration and its legislative provision were studied by the author. Authors claim that the developed rules of the effective social welfare provision in the activity of the business entities characterize development of theoretical issues and social welfare provision in context of sustainable development. 
3.2. Descriptive statistics. Practical grounds of the consequences of the minimum salary increase for the entities of the business sector should be analyzed. Thus, for the entrepreneurs, who are paying the united tax, minimal compulsory tax payments will double: for $10 \%$ for the first group and for $20 \%$ for the second group. So, in 2017, these entrepreneurs will have to pay to the state 3840 UAH (143 USD) and 7680 UAH (286 USD) for the united tax payers only (comparing to the numbers of 2016: 1653.6 UAH (61 USD) and 3307.2 UAH (123 USD) correspondently). There also exist united social tax compulsory payments (UST) for the individual entrepreneurs of the simplified tax system. In 2017 these payments will comprise 8448 UAH (314 USD) comparing to the 3797.64 UAH (141 USD) in 2016 (Zhuck, 2016).

Practical issues of the social welfare provision in the activity of business entities of the enterprises: TOV "BBB" (Sumy), TOV "Avtogazproject" (Dnipro), TOV "LMG" (Sumy) should be analyzed. Incoming data in the Table 1 are presented on the basis of reports about the labour remuneration and reports about the amount of accounted salary in TOV "BBB" (Sumy), TOV "Avtogazproject" (Dnipro), TOV "LMG" (Sumy) during the period 2015-2016.
Table 1. Incoming information about labour remuneration and social tax payments made by business organizations TOV "BBB”, TOV “Avtogazproject", TOV

"LMG" (according to the financial reporting data)

\begin{tabular}{|l|c|c|c|}
\hline \multicolumn{1}{|c|}{ Name of the index } & TOV "BBB" & $\begin{array}{c}\text { TOV } \\
\text { "Avtogazproject" }\end{array}$ & $\begin{array}{c}\text { TOV } \\
\text { "LMG" }\end{array}$ \\
\hline $\begin{array}{l}\text { Total number of employees, } \\
\text { person }\end{array}$ & 3 & 8 & 10 \\
\hline $\begin{array}{l}\text { Number of employees with } \\
\text { minimum salary, person }\end{array}$ & 2 & 6 & 8 \\
\hline $\begin{array}{l}\text { Minimum salary in 2015 (as of } \\
\text { 31.12.2015), UAH (USD) }\end{array}$ & $1378(60)$ & $1378(60)$ & $\begin{array}{c}1378 \\
(60)\end{array}$ \\
\hline $\begin{array}{l}\text { Minimum salary in 2016 (as of } \\
\text { 31.12.2016), UAH (USD) }\end{array}$ & $1600(60)$ & $1600(60)$ & $\begin{array}{c}1600 \\
(60)\end{array}$ \\
\hline United socialtax in 2015,\% & 36,76 & 37,5 & 36,76 \\
\hline United socialtax in 2016,\% & 22 & 22 & 22 \\
\hline Personal income tax in 2015, \% & 15 & 15 & 15 \\
\hline Personal income tax in 2016, \% & 18 & 18 & 18 \\
\hline War tax,\% & 1,5 & 1,5 & 1,5 \\
\hline
\end{tabular}

After obtaining incoming information it is necessary to make a comparative analysis of the research of the business entities' activity.

3.3. Comparative statistical analysis. There should be studied salary growth level and social contributions during the period of the fourth quarter of 2015-2016 and predicted first quarter of the 2017 in the activity of the enterprises TOV "BBB", TOV "Avtogazproject", TOV "LMG" (Table 2). Tax burden was estimated according to the following values, which are set as a norm by regulations for 2017: so, united social tax $22 \%$ (united social tax, 2016), personal income tax $18 \%$ (PIT, 2016), war tax - 1.5\% (war tax, 2016).

Table 2. Comparative analysis of the payroll budget and social contributions in the activity of TOV "BBB", TOV "Avtogazproject", TOV "LMG" (developed by the authors)

\begin{tabular}{|c|c|c|c|c|c|}
\hline \multirow[b]{2}{*}{ Index } & \multicolumn{3}{|c|}{ Years } & \multirow{2}{*}{$\begin{array}{l}\text { Deviations 2015/ } \\
2016, \%\end{array}$} & \multirow{2}{*}{$\begin{array}{c}\text { Deviations } 2015 \text { / } \\
2017, \%\end{array}$} \\
\hline & $\begin{array}{c}2015 \\
\text { (4 quart.) }\end{array}$ & $\begin{array}{c}2016 \\
\text { (4 quart.) }\end{array}$ & $\begin{array}{c}2017 \\
\text { (pred. quart.) }\end{array}$ & & \\
\hline \multicolumn{6}{|c|}{ TOV "BBB" } \\
\hline Payroll budget, UAH (USD) & $\begin{array}{l}12768 \\
(552)\end{array}$ & $\begin{array}{l}13650 \\
(508)\end{array}$ & $\begin{array}{l}29700 \\
(1105)\end{array}$ & 107 & 233 \\
\hline United social tax, UAH (USD) & $\begin{array}{l}4694 \\
(203)\end{array}$ & $\begin{array}{l}3003 \\
(112)\end{array}$ & $\begin{array}{l}6534 \\
(243)\end{array}$ & 64 & 139 \\
\hline Personal income tax, UAH (USD) & $\begin{array}{l}1915 \\
(83)\end{array}$ & $\begin{array}{c}2457 \\
(91)\end{array}$ & $\begin{array}{l}5346 \\
(199) \\
\end{array}$ & 128 & 279 \\
\hline War Tax, UAH (USD) & $\begin{array}{l}192 \\
(8)\end{array}$ & $\begin{array}{l}205 \\
(8)\end{array}$ & $\begin{array}{l}446 \\
(17)\end{array}$ & 107 & 233 \\
\hline $\begin{array}{l}\text { Total expenditures for the labour remuneration, UAH } \\
\text { (USD) }\end{array}$ & $\begin{array}{l}19569 \\
(846)\end{array}$ & $\begin{array}{l}19315 \\
(719)\end{array}$ & $\begin{array}{l}42026 \\
(1564) \\
\end{array}$ & 99 & 215 \\
\hline \multicolumn{6}{|c|}{ TOV "Avtogazproject" } \\
\hline Payroll budget, UAH (USD) & $\begin{array}{l}35304 \\
(1526)\end{array}$ & $\begin{array}{l}38700 \\
(1439)\end{array}$ & $\begin{array}{l}78900 \\
(2934)\end{array}$ & 110 & 224 \\
\hline United social tax, UAH (USD) & $\begin{array}{c}13239 \\
(572)\end{array}$ & $\begin{array}{l}8514 \\
(317)\end{array}$ & $\begin{array}{c}17358 \\
(646)\end{array}$ & 64 & 131 \\
\hline Personal income tax, UAH (USD) & $\begin{array}{l}5296 \\
(229)\end{array}$ & $\begin{array}{l}6966 \\
(259)\end{array}$ & $\begin{array}{c}14202 \\
(528)\end{array}$ & 132 & 268 \\
\hline War Tax, UAH (USD) & $\begin{array}{l}530 \\
(23)\end{array}$ & $\begin{array}{l}581 \\
(22)\end{array}$ & $\begin{array}{c}1184 \\
(44)\end{array}$ & 110 & 224 \\
\hline $\begin{array}{l}\text { Total expenditures for the labour remuneration, UAH } \\
\text { (USD) }\end{array}$ & $\begin{array}{l}54369 \\
(2350)\end{array}$ & $\begin{array}{l}54761 \\
(2037)\end{array}$ & $\begin{array}{c}111644 \\
(4152)\end{array}$ & 101 & 205 \\
\hline
\end{tabular}


Table 2 (cont.). Comparative analysis of the payroll budget and social contributions in the activity of TOV "BBB", TOV "Avtogazproject", TOV "LMG" (developed by the authors)

\begin{tabular}{|c|c|c|c|c|c|}
\hline \multirow[b]{2}{*}{ Index } & \multicolumn{3}{|c|}{ Years } & \multirow{2}{*}{$\begin{array}{l}\text { Deviations 2015/ } \\
\quad 2016, \%\end{array}$} & \multirow[b]{2}{*}{$\begin{array}{c}\text { Deviations 2015/ } \\
2017, \%\end{array}$} \\
\hline & $\begin{array}{c}2015 \\
\text { (4 quart.) }\end{array}$ & $\begin{array}{c}2016 \\
\text { (4 quart.) }\end{array}$ & $\begin{array}{c}2017 \\
\text { (pred. quart.) }\end{array}$ & & \\
\hline \multicolumn{6}{|c|}{ TOV "LMG" } \\
\hline Payroll budget, UAH (USD) & $\begin{array}{l}42972 \\
(1858)\end{array}$ & $\begin{array}{l}46350 \\
(1724)\end{array}$ & $\begin{array}{l}97500 \\
(3626)\end{array}$ & 108 & 227 \\
\hline United social tax, UAH (USD) & $\begin{array}{l}15797 \\
(683)\end{array}$ & $\begin{array}{l}10197 \\
(379)\end{array}$ & $\begin{array}{c}21450 \\
(798)\end{array}$ & 65 & 136 \\
\hline Personal Income tax, UAH (USD) & $\begin{array}{l}6446 \\
(279)\end{array}$ & $\begin{array}{l}8343 \\
(310)\end{array}$ & $\begin{array}{c}17550 \\
(653)\end{array}$ & 129 & 272 \\
\hline War Tax, UAH (USD) & $\begin{array}{l}645 \\
(28)\end{array}$ & $\begin{array}{l}695 \\
(26)\end{array}$ & $\begin{array}{l}1463 \\
(54)\end{array}$ & 108 & 227 \\
\hline $\begin{array}{l}\text { Total expenditures for the labour remuneration, } \mathrm{UAH} \\
\text { (USD) }\end{array}$ & $\begin{array}{l}65860 \\
(2848)\end{array}$ & $\begin{array}{l}65585 \\
(2439)\end{array}$ & $\begin{array}{l}137963 \\
(5131)\end{array}$ & 100 & 210 \\
\hline
\end{tabular}

Taking into account National Bank of Ukraine currency exchange rate as of the date of estimation (USD/UAH 1:23.13 in 2015; 1:26.89 in 2016), the great leap of expenditures for the labour remuneration in the predicted period was established. In TOV "BBB" it amounted 215\%, in TOV "Avtogazproject" it amounted $205 \%$, and in TOV "LMG" $-210 \%$. This growth of expenditures is certainly a negative factor, and it influences the cost of all business processes and additional cost of the performed services for all participants of the business sector.

3.4. Regressive analysis. Regressive analysis, which characterizes formation of the regressive function of four variables and formation of the mathematical equation $(y)$ of dependence of the payroll budget (accounting the minimum salary growth) and social contributions, should be conducted.

$y=\sum_{l=1}^{n} f\left(X_{1}, X_{2}, X_{3}, X_{4}\right) \rightarrow \min$,

where $f-$ the function of the description of the payroll budget and social contributions dependence; incoming data: $X_{1}$-payroll budget; $X_{2}$ - united social tax; $X_{3}$ - personal income tax; $X_{4}-$ war tax; $n$ number of business entities.

Herewith, it is necessary to state some limits for this function, namely:

$X_{1} \geq 0 ; X_{2} \geq 0 ; X_{3} \geq 0 ; X_{4} \geq 0 ; n \in[0 ; \infty] ;$

$u_{2}=$ const $; u_{3}=$ const $; u_{4}=$ const

where $u_{2}$ - rate of the united social tax account; $u_{3}$ rate of the personal income tax account; $u_{4}$ - rate of the war tax account.

During the research, authors distinguished following economic models $y_{1}, y_{2}, y_{3}, y_{4}$, which characterize dependence of the payroll budget (accounting the minimum salary growth) on the variable of united social tax payment $f\left(X_{1}, X_{2}\right)$, personal income tax $f\left(X_{1}, X_{3}\right)$, war tax $f\left(X_{1}, X_{4}\right)$; total social contributions $f\left(X_{1}, X_{2}, X_{3}, X_{4}\right)$. These models are presented in the Fig. 2.

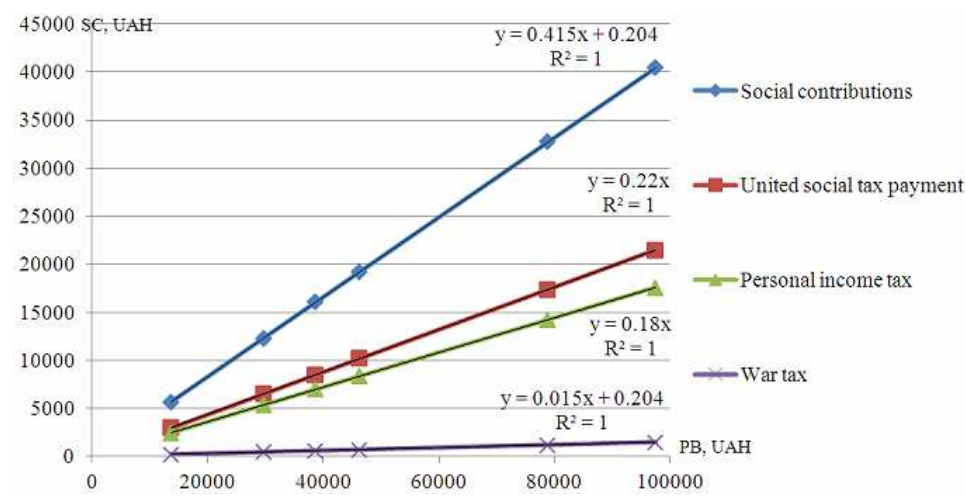

Fig. 2. Payroll budget dependency diagamm, accounting variations in the minimum salary changes and payroll taxes (developed by the authors)

During investigation, it was established that functions of the payroll budget dependence on the social contributions are presented by the simple linear regression, that is substantiated by the dependence of the payroll budget growth level (PB) (axis $O X$, independent vari- able, characterizing the salary value- $x$, size [0-3719] (USD)), on the growth of the amount of the social contributions (SC) (axis OY, size [0-1673] (USD)) (UAH /USD currency exchange rate of the National Bank of Ukraine on the date of estimation: December, 2016 
(1:26.89). Also, linear equations, presented in the Fig.2 were chosen according to the criteria $R^{2} \rightarrow \max$ which means the maximization of the approximation consistency, which increases authenticity of the obtained data.

4. Discussion. The authors proved that the established dependence between the growth of the payroll budget by means of minimum labor remuneration growth and increase of social contributions has negative influence on the economical activity of the business entities because it influences the increase of the tax burden rate in their activity. In the works of I.M. Sotnik, T.V. Yakushko, both scientistseconomists (Sotnik, Yakushko, 2016), it is also stated that the level of the minimum salary in 2015 remains on the level of 2010 and does not fulfill social functions and leads to employees' demotivation. One more important issue, which influences the increase of social standards level, is the presence of sufficient amount of current capital for effective activity of business entities. While formating of the dependence function of the payroll budget from the social contributions, it is necessary to mention the limitations of this function, namely, rates of the tax burden, which have to be constant. Implementation of this condition allows the possibility to increase the obtained results authenticity and to decrease inaccuracy of calculations. The settled economical models, which characterize the functions of the dependence of the payroll budget from the social contributions, give an opportunity to distinguish the interrelation among four variables and to study the level of deviation from the control (trend) value of dependence of the payroll budget from social contributions.

5. Consequences for administration. The authors declare that the sharp increase of the minimum salary leads to the increase of the level of social contributions for the business sector and, as a result, stuff reduction and introduction of the shadow schemes of salary payment. Thus, there is the necessity to optimize tax burden in the context of the minimum salary increase in the business entities activity. The authors state that in the business administration, it is necessary to offer organization-economic measures, oriented on the decrease of the tax burden in the context of transition to the sustainable development. These organizationeconomic measures are the following:

- decrease of the tax rates of the social contributions for the business entities, which can lead to unshadowing of the business and payment of legal salaries without shadow schemes;
- introduction of the tax holidays for the entrepreneurs, whose business is younger than one year, that gives an opportunity to build up the volume of turnover capital for the effective further administration;

- decrease of the loan rate for the business sector till $10 \%$ per year, with following decrease till $3 \%$ in the context of sustainable development. This measure can influence the investments in the business sector;

- introduction of business patterns with collateralized property, which will create the capital stock of the business organization for the case of loan debt. This method will lead to the decrease of risks of nonpayment for the material assets and other payments by the business entities;

- implementation of the state programs of the investor attraction to the business sector. They are aimed at creation of the new working places in the region and increase of the salary for the employees.

Accomplishment of these organization-economic measures will solve existing for the present day administration problem in the social sphere for the business entities and implement the main rules of sustainable development.

\section{Conclusions and directions for further researches.}

The main problematic aspects of the social provision in the social sphere were studied. The existing scientific views for the social provision process and its role in the economic activity of the business entities were examined. The comparative analysis of the payroll budget and social contributions in the work of TOV "BBB", TOV "Avtogazproject", TOV "LMG" was performed. Direct linear regression between the payroll budget increase, accounting the level of the minimum salary and social contributions was established. Organization-economic measures of the tax burden decrease for the business entities were offered. For the further scientific researches on this topic, authors offer not to be limited only by examination of the monetary policy, but to study this problem in complex with analysis of investment and financial provision of business organizations' activity, building-up of organization-economic provision of employees motivation rewards in the work of business entities.

Acknowledgement. This research was funded by a grants: (No M/50 -2016, № g/r 0116U007179) from the Ministry of Education and Science of Ukraine and (No. TAP LU-4-2016) from the Research Council of Lithuania.

\section{References}

1. Strochenko, N.I. (2014). Metodologiia rozvitku preventivnogo normativnogo zabeapechennia ekologizacii ekonomiki, Visnik Natsionalnogo universitetu vodnogo gospodarstva ta prirodokoristuvanniia, 4 (68), pp. 391-399.

2. Antikrizova programma spilnih diy vlady I biznesu: nevidkladni rishenniia. (2016). Potochna Socialno-ekonomichna situatsiia. Kyiv: USPP, 8. 
3. Bagatogaluzeva statistichna informatsiia. (2016). Osnovni pokazniki socialno - ekonomichnogo rozvitku Ukraini (shchomisiachna informatsiia). Rezhim dostupu: http://www.ukrstat.gov.ua.

4. Novin Ukrainskogo soyuzu promislovtsiv i pidpriemtsiv. (2016). V Kharkivskomu RVUSPP proanalozuvali naslidki pidvishshenniia rivnia minimalnoi zarobitnoi platy. Rezhim dostupu: http://uspp.ua/v-xarkivskomu-rv-usppproanalizuvali-naslidki-pidvishhennya-rivnya-minimalnoi-zarobitnoi-plati.html.

5. Makhinchuk, V.M. (2013). Sub'ekty pidpriyemnitskoi diialnosti za tsivilnim ta gospodarskim zakonodavstvom Ukraini, Privatne parvo tapidpriemnitstvo, 12, pp. 28-32.

6. Melnik, L.G. (2010).Zakonomernosti funktsionirovaniia I razvitiia socialno - ekonomiceskih system, Aktualni problem ekonomiki, 6 (108), pp. 41-47.

7. Melnyk, L.G., Shkarupa, E.V. and Kharchenko, M.O. (2013). Innovative Strategies to Increase Economic Efficiency of Greening the Economy, Middle-East Journal of Scientific Research, 16 (1), pp. 30-37.

8. Sotnyk, I., Kurbatova, T.and Khlyap, H. (2014).Economical mechanisms for renewable energy stimulation in Ukraine, Renewable and Sustainable Energy Reviews, 31, pp. 486-491.

9. Kundenko, A.,Dorosh, M.,Baraniuk, I. andItchenko, D. (2015).Crisis management of small and medium businesses in regional economic policy system, EconomicAnnals-XXI, 5-6, pp. 108-111.

10. Malyovanyi, M., Rolinskyi, O. and Lysa, N. (2016). Selected aspects of the social protection system's financial security in the context of shadow economy, Economic Annals-XXI, 158 (3-4(2)), pp. 88-91.

11. Estrin, S., Mickiewicz, T., Stephan, U. (2016). Human capital in social and commercial entrepreneurship, Journal of Business Venturing, 31, pp. 449-467.

12. Irengun, O. and Arikboga, S. (2015). The effect of personality traits onsocial entrepreneurshipintentions: a field research, Procedia - Social and Behavioral Sciences, 195, pp. 1186-1195.

13. Cheslock, J.J. and Callie, T.M. (2015).Changing salary structure and faculty composition within business schools: Differences across sectors and state funding levels, Economics of Education Review, 49, pp. 42-54.

14. Malul, M. and Shoham, A. (2013).The salariesof CEOs: Is it all about skills? Journal of Economics and Business, 67 , pp. 67-76.

15. Ng, T. and Feldman, D. (2014). A conservation of resources perspective on career hurdles and salary attainment. Journal of Vocational Behavior, 85 (1), pp. 156-168.

16. More, J. (2014). Salary Negotiation: Everything Can Be Flexible, Job Reconnaissance, 16, pp. 145-150.

17. Gorodniia, T.A. i Kaniuka, N.S. (2012). Otsinka vartosti pidpriemstva v suchasnih umovah, Staliy rozvitok ekonomiki, 7 , pp. 111-114.

18. Kalinichenko, A.V. i Shmigol, Y.V. (2011). Prognozuvanniia za dopomogoyu funktsiy regressii.Rezhim dostupu: http://khntusg.com.ua/files/sbornik/vestnik 104/02.pdf.

19. Gilpin, G.A. (2012). Teacher salaries and teacher aptitude: An analysis using quantile regressions, Economics of Education Review, 31 (3), pp. 15-29.

20. Polishchuk, N. (2015). Minimalna zarobitna plata sered krain svitu ta v Ukraini (dinamika ta geografiia 2005-2015). Rezhim dostupu: http://infolight.org.ua/content/minimalna-zarobitna-plata-sered-krayin-svitu-ta-v-ukrayini-dynamikata-geografiya-2005-2015-rr.

21. Gorodnichenko, Y. i Talaver, O. (2016).Pratsia i podatki: Do chogo prizvede podvoyenniia zarobitnoii platy. Dosvid Ugorschini ta Rossii. Rezhim dostupu: http://voxukraine.org/2016/12/06/minimum-wage-and-tax-evasion-ua.

22. Tonin, M. (2011). Minimum wage and tax evasion: theory and evidence.Journal of Public Economics, 95 (11-12), pp. $1635-1651$.

23. Muravyev, A., and Oshchepkov, A. (2015). The Effect of Doubling the Minimum Wage on Employment: Evidence from Russia, DiscussionPaper, 9589, 26.

24. Pyshulina, O. M (2007). Socialne znachennia minimalnoi zarobitnoi platy ta ii rol' u formuvannii tsini robochoi sily na rinku pratsi Ukraini. Strategichni prioritety, 4 (5), pp. 134-141.

25. Zhuck, V. (2016). Skilki zaplatit biznes za minimalku u 3200 grn: rozrahunki dlia eydinnikiv ta yurosib. Rezhim dostupu: http:/hgraf.com.ua/index.php/joomla-pages/joomla-content/item/6897-skilki-zaplatit-biznes-za-minimalku-u3200-grn-rozrakhunki-dlya-edinnikiv-i-yurosib.

26. Yediniy socialniy vnesok. (2016). Yediniy socialniy vnesok u 2017 rotsi v Ukraini. Rezhim dostupu: http://dovidkam.com/porady/yedinij-socialnij-vnesok-u-2017-roci-v-ukra\%D1\%97ni.html.

27. Podatok z dohodiv fizichnih osib (2016).PDFOu 2017 rotsi $v$ Ukraini. Rezhim dostupu: http://dovidkam.com/porady/pdfo-u-2017-roci-v-ukra\%D1\%97ni.html.

28. Voyenniy sbor. (2016). Izmeneniya $v$ voennom sbore $v 2017$ godu $v$ Ukraine. Rezhim dostupu: http://myukraina.com.ua/finansy/nalogi/izmeneniya-v-voennom-sbore-v-2017-godu-v-ukraine.html.

29. Sotnik, I.M. i Yakushko, T.V. (2016) Problemi viznachennia rivnia minimalnoi zarobitnoi platy v Ukraini. Resursniy potentsial regioniv Ukraini: stan ta napriamy rozvitku: materialy mizhnarodnoi naukovo-praktichnoi konferentsii ( $L$ 'viv, 29-30 sichnia 2016 roku), 2, pp. 40-45. 